\title{
ВИКОРИСТАННЯ ІНФОРМАЦЙНИХ ТЕХНОЛОГІЙ У НАВЧАЛЬНОМУ ПРОЦЕСІ ТА СТВОРЕННЯ ЕЛЕКТРОННОГО ПІДРУЧНИКА
}

\author{
О. В. Швидкий, О. А. Хадикіна, В. С. Малиновська \\ Донечький базовий медичний коледж
}

\section{USING THE INFORMATION TECHNOLOGIES IN THE EDUCATIONAL PROCESS AND CREATING AN ELECTRONIC TEXT-BOOK

\author{
O. V.Shvydkyi, O.A. Khadykina, V.S. Malynovska \\ Donetsk Basic Medical College
}

\begin{abstract}
Інформаційні технології відкривають студентам доступ до нетрадиційних джерел інформації, підвищують ефективність самостійної роботи, відкривають нові можливості для творчості, дозволяють реалізувати принципово нові форми й методи навчання.

The information technologies open an access for students to non-traditional sources of information, increase the effectiveness of an individual work, give the new possibilities for creative work, allow to realize the substantially new forms and methods of education.
\end{abstract}

Вступ. Сучасні інноваційні методи навчання базуються на інформаційних технологіях подачі матеріалу, контролю знань, організації самостійної роботи. Викладачі Донецького базового медичного коледжу у своій педагогічній діяльності з метою формування пізнавальних інтересів студентів використовують форми, методи, засоби викладання, що забезпечують активність студентів і дають можливість підвищити їх рівень знань і вмінь.

Основна частина. Дидактика завжди займалася питанням: “Як переробити й передати інформацію, щоб вона була найкраще засвоєна?”. Широке використання комп'ютерів у навчанні привело до появи терміна “інформаційні технології навчання”. Під інформаційними технологіями розуміють сукупність методів і технічних засобів збору, організації, обробки, зберігання, передачі й надання інформації, яка розширює знання людей і розвиває їх можливості 3 керування технічними й соціальними процесами [4]. Нові інформаційні технології в навчанні - це методологія й технологія навчально-виховного процесу з використанням новітніх електронних засобів навчання.

Сучасне заняття слід розглядати у вигляді потоку інформації від викладача до студентів. Технології, які застосовуються для керування цим потоком інформації, і $є$ інформаційні технології. Їх різновидом $\epsilon$ дистанційне навчання й кейс-технології. Дистан- ціийне навчання - навчання, при якому увесь або більша частина навчального процесу здійснюється 3 використанням сучасних інформаційних і телекомунікаційних технологій притериторіальній роз'єднаності викладача й студентів [5]. Кейс-технологія - вид дистанційної технології навчання, заснований на використанні наборів (кейсів) текстових, аудіовізуальних і мультимедійних навчально-методичних матеріалів для самостійного опанування студентами, при організації регулярних консультацій у викладачів традиційним або дистанційним способом [5].

У навчальному процесі інформація має подаватися із застосуванням необхідної наочності, що збуджує механізм сприйняття, інтерес до даної галузі знань і до навчання взагалі. Застосування нових технічних засобів навчання дає можливість зробити заняття змістовним і цікавим, полегшити розуміння важких запитань, підняти науковий рівень і творчий характер викладу; передбачає перехід від традиційних форм навчання з переважно пояснювально-ілюстративною методикою до збільшення обсягу навчальних завдань пошуково-дослідницького характеру.

3 досвіду роботи викладачів коледжу визначилися переваги навчання із застосуванням інформаційних технологій навчання. Вони дозволяють засвоїти більше за обсягом і за якістю подачі навчального матеріалу, дозволяють контролювати індивідуальний

() О. В. Швидкий, О. А. Хадикіна, В. С. Малиновська 
темп навчальної діяльності (при роботі з комп'ютером у студента є можливість самостійно обрати момент переходу до наступної порції навчальної інформації, задавати швидкість подачі завдань, час розв’язування завдань), дають студентові можливість самостійно переходити від більш важкого навчального матеріалу до більш легкого й навпаки, створюють образотворчі ефекти.

Комп'ютеризація навчання вирішує досить складні завдання самостійного засвоєння знань, міняє статус студента, він усвідомлює себе людиною, яка самостійно ухвалює певні рішення й відповідає за отриманий результат. Також використання електронних засобів у процесі навчання дозволяє підвищити інтерес і загальну мотивацію навчання завдяки індивідуалізації навчання - кожний студент працює в режимі, який його задовольняє, забезпечується доступ студентів до “банку інформаці1”, є можливість оперативно одержувати необхідні дані в достатньому обсязі.

До електронних засобів навчального призначення можна віднести: мультимедійний навчальний проект з конкретної дисципліни, мультимедійну презентацію, електронний підручник, навчально-ігрові програми, комп'ютерну енциклопедію, навчально-демонстраційні й контролюючі програми, довідкову комп’ютерну базу даних тощо.

Створюваний програмний продукт повинен відповідати педагогічним, методичним, фізіолого-гігієнічним і технічним вимогам, а також мати супровідні матеріали, що допомагають найбільш ефективно використовувати його в навчальному процесі.

Викладачами коледжу широко використовуються інформаційні технології під час викладання лекції, а саме використання мультимедійних презентацій. Мультимедіa - сукупність комп'ютерних технологій, де одночасно використовується кілька інформаційних середовищ: графіка, текст, відео, фотографія, звукові ефекти.

Ми звикли до того, що лекційна інформація подається за допомогою усного викладу. Сприйняття й засвоєння такого лекційного матеріалу представляє 810 \% від викладеного матеріалу, а зоровий аналізатор дозволяє сприймати до 90 \% інформації. Якщо ми прагнемо бути почутими нашими студентами, то необхідно адаптувати матеріали навчальних дисциплін до рівня, на якому студенти будуть їх сприймати. Мультимедійні технології відіграють позитивну роль у мотивації навчальної діяльності, полегшують процес спілкування викладачів і студентів під час викладу нового навчального матеріалу. На ек- рані зручно відображати відеофрагменти клінічних прикладів хворих, малюнки, графічні схеми, таблиці. Студенти краще розуміють матеріал лекції, правильно записують нові малозрозумілі терміни. У викладача $\epsilon$ можливість найбільш оптимально викласти матеріал лекції за часом (при наявності 25-30 слайдів щільність їх показу буде представляти 25-30 хвилин).

Підготовка мультимедійної презентації лекції для кращого засвоєння матеріалу потребує виконання декількох правил:

1. Виносити на слайд тільки головне, нічого другорядного.

2. Уникати значних обсягів текстового матеріалу (студент повинен реально встигнути прочитати текст, можна застосовувати схеми).

3. Підбирати правильно колір для слайдів (нейтральні, неагресивні кольори, враховуючи, що на білому фоні матеріал погано сприймається).

4. Включати більше малюнків.

5. Орієнтувати час експозиції слайда на студента.

6. Не перевищувати кількість слайдів більш 25-30 на лекцію.

Для методичного забезпечення практичного заняття викладачі коледжу також використовують інформаційні технології. На практичних заняттях студенти коледжу можуть працювати із прикладними програмами. У програмі Meddoc пишуть історії хвороби, заповнюють аркуш призначень, лабораторні дані заносять у лист лабораторних досліджень, працюють iз температурним аркушем. Робота 3 програмою допомагає студентам встановлювати діагноз, проводити обстеження, формує навички роботи з документацією. Програма використовується на заняттях з терапії, педіатрії, хірургії, інфекційних хвороб.

Застосування програми тестового контролю Крок М, яка включає питання 3 клінічних дисциплін, дає студентам можливість самостійно працювати з тестовими завданнями як під час навчання, так і під час контролю знань, наприклад, перед захистом практики, на іспитах тощо. Крім того, у програмі передбачена робота над помилками, що дає студентам можливість більш повно засвоїти навчальний матеріал.

Навчальна функція комп'ютера на практичному занятті може використовуватися як тренажер для формування й закріплення вмінь і навичок та як репетитор, який виконує деякі завдання за викладача, як обладнання, яке моделює певні предметні ситуації.

Інформаційні технології дозволяють урізноманітнити організацію самостійної роботи студентів. Основними пріоритетами в цьому напрямку є: підготовка в бібліотеці коледжу комп'ютерних баз даних, довід- 
кових каталогів, впровадження нових електронних систем обслуговування студентів і викладачів; розробка дидактичних матеріалів нового покоління, адаптованих для самостійної роботи; використання електронних підручників і віртуальних засобів навчання.

У коледжі більша частина методичних рекомендацій для самостійної роботи студентів виконана у вигляді електронних підручників. В них включені методичні рекомендації для самостійного опанування навчального матеріалу, короткі теоретичні дані, питання для самоконтролю згідно зі ступенем засвоювання вивченого матеріалу, форми підсумкового контролю, перелік літератури, обов'язкові посилання на нормативну документацію, довідкові дані, ілюстративний матеріал тощо. При цьому слід зазначити, що електронні носії інформації дозволяють при малих розмірах умістити великий їі обсяг, легко тиражуються й економічно вигідніші.

У коледжі ведеться активна робота по створенню електронних підручників. Електронний підручникце якісний програмно-методичний комплекс, що забезпечує можливість студентам, під керівництвом викладача або самостійно, засвоювати навчальний курс, згідно із програмами дисципліни, з використанням можливостей комп'ютерних технологій [5]. Електронний підручник повинен розроблятися на досить високому науковому й методичному рівні.

Організацію й розробку програмного продукту в коледжі здійснюють викладач інформатики й викладач дисципліни, для якоїпризначений підручник, а сама робота іноді виконується силами студентів під час практичних робіт у гуртках програмування й інформатики, самостійної роботи. Звичайно ж, ця робота вимагає багато часу, спеціальних знань, умінь, навичок.

Основними етапами розробки електронного підручника $\epsilon$ : підготовка змістовно наповнених навчальнометодичних матеріалів в електронному варіанті, вибір джерел (матеріалу), розміщення матеріалу згідно зі структурою електронного підручника, визначення зв’ язків між матеріалами, вибір матеріалу для мультимедійного втілення, розробка звукового супроводу, підготовка матеріалу для візуалізації (розробка сценарію), візуалізація матеріалу (комп’ютерне втілення розробленого сценарію).

У коледжі ми використовуємо таку структуру електронного підручника:

Головна Web-сторінка містить:

· назву навчального закладу;

· назву курсу (дисципліни).

Друга Web-сторінка містить: вступну частину:

• П.І.Б. автора, його фото й коротка виробнича характеристика (освіта, кваліфікація, кваліфікаційна категорія, вчене й педагогічне звання, педагогічний стаж);

· анотація курсу (дисципліни);

· ціль курсу (дисципліни);

- тривалість вивчення курсу (дисципліни);

· інструкція роботи з електронним підручником;

інформачійну частину:

· план з навчальної дисципліни;

змістовну частину:

· лекцї;

· інструктивно-методичні матеріали до практичних занять;

· інструктивно-методичні матеріали до семінарських занять;

- інструктивно-методичні матеріали до позааудиторної самостійної роботи;

- термінологічний словник;

- література;

• довідник;

контрольно-моніторингову частину:

- засоби діагностики (тестові завдання) підсумкового контролю (семестровий іспит і диференційований залік);

• критерії оцінювання.

При створенні електронного підручника ми використовуємо гіпертекстовий формат, який дозволяє розробляти навчальні посібники з якісно новими можливостями візуалізації навчального процесу. Можлива інтеграція графіки, відео-, аудіоінформації, а включення в підручник Flash-анімації дозволяє моделювати процеси, що важко представити візуально. До такої анімації ставляться динамічні моделі, діаграми, що “плавають”, структурно-логічні схеми, кольорові ілюстрації, схематичні підказки. Працюючи над створенням електронного підручника, необхідно пам'ятати про те, що ним будуть користуватися викладачі й студенти, тому його важливо супроводити методичними порадами для викладача й поясненнями для студентів. Розроблені викладачами коледжу електронні підручники ми розміщуємо у мережі "Інтернет" та на сайті коледжу.

Висновок. Інформаційні технології відкривають студентам доступ до нетрадиційних джерел інформації, підвищують ефективність самостійної роботи, відкривають нові можливості для творчості, дозволяють реалізувати принципово нові форми й методи навчання. 


\section{Лiтература}

1. Прокопенко Й. Ф. Педагогічні технології : навчальний посібник / Й. Ф. Прокопенко, В. І. Свдокімов. - Харків : ХДПУ, 1995.-104 c.

2. Янушевич Ф. Технологія навчання в системі вищої освіти / Ф. Янушевич. - М. : Вища школа, 1986.

3. Мій комп'ютер. Всеукраїнський тижневик. - 2005. №2-12.

4. Зиміна О. В. Друковані й електронні навчальні видання у сучасній вищій освіті: теорія, методика, практика / О. В. Зиміна. - М. : МЭИ, 2003.
5. Бутикова Л. С. Нові пріоритети розвитку сучасної освіти / Л. С. Бутикова. -К. : Вища освіта України, 2006. - № 3. - C. 83-88.

6. Врублевська С. В. Інноваційні процеси у системі освіти / С. В. Врублевська. // Мед. освіта. - 2007. - № 1. - С. 4348.

7. Даниленко Л. І. Педагогічні інноваційні технології: сутність і структура // Нові технології навчання. Наук.-метод. зб. / кол. авт. - КНМЦВО, 2005. - Вип. 40. - С. 270-276. 